Pak. j. sci. ind. res. Ser. B: biol. sci. 2019 62B(3) 164-171

\title{
Paracetamol-Induced Liver Damage and Effect of Prosopis africana Seeds Extract on Liver Marker Enzymes of Wistar Albino Rats
}

\author{
Joshua Parker Elijah*, Anosike Joy Chizoba, Victor Eshu Okpashi and \\ Chilentugo Nwodo Okwesili Fred
}

Department of Biochemistry, University of Nigeria, Nigeria

(received December 2, 2016; revised April 20, 2018; accepted April 23, 2018)

\begin{abstract}
This study was carried to determine the effect of Prosopis africana seed extract after induction of paracetamol in Wistar albino rats to ascertain its ameliorating capacities in terms of liver damage. The assay was done on alkaline phosphatase, alanine aminotransferase, aspartate aminotransferase, and hematological parameters. Thirty-two Wistar albino rats with an average weight of 120-180 g were used for this investigation. The $P$. africana seeds were extracted by maceration after $24 \mathrm{~h}$ fermentation in chloroform-methanol ratio $2: 1$. The animals were administered $2500 \mathrm{mg} / \mathrm{kg}$ of paracetamol upon $24 \mathrm{~h}$ starvation to induce liver damage. After administering $5000 \mathrm{mg} / \mathrm{kg}$ body weight (BW), the extract showed no acute toxicity. Serum alanine phosphatase, alanine aminotransferase, and aspartate aminotransferase levels decreased in all the test groups as compared to paracetamol group. The results depicted that $P$. africana seeds extract are effective in the regeneration of the damaged liver cells by averting enzyme leakage into the bloodstream.
\end{abstract}

Keywords: paracetamol, Prosopis africana, liver marker, enzymes, diabetes

\section{Introduction}

Researchers have found the use of medicinal plants as mujor source of treating disease such as Garcinia kola, with tremendous benefit for treating asthma, Carica papaya to cure hypertension, Ocimum basilicum a medicament for typhoid fever and Cola nitida for treating pile (FAO, 1996). In some West African countries such as Nigeria, fermented Prosopis africana seeds are used as a food seasoning. According to Kolapo et al. (2009), the stem and roots of $P$. africana have the potential for dentifrices production. The bark of $P$. africana was used by Lawal et al. (2010) to study its effect on the pile. The anticonvulsant activities of $P$. africana were observed after inducing convulsion with STR (strychnine) and PTZ (pentylenetetrazol). The plant extract was able to resist the effect of PTZ and STR induced convulsions (Ngo-Bum et al., 2009). The $P$. africana plant extract was checked for its antitrypanosomal activity (Osho and Lajide, 2012). They reported the plant's bioactive ingredients which may help with the production of trypanocide that is potent and less toxic than other trypanocidal drugs. The P. africana is in the family of Fabaceae, it employs locally in phytomedicine in most African nations. This includes their uses for treating headache and toothache; their leaves and stem bark are mixed together in

*Author for correspondence;E-mail: parker.joshua@unn.edu.ng managing rheumatism, the roots are applied for treating diuretic and dysentery, bronchitis, and stomach cramps (Arbonnier, 2002: Gilbert and Neil, 1986). Prosopis liquid is used as bio-adhesive agent or emulsifier to deliver metformin a therapy for diabetes. This illustrated the diverse application of the plants (Momoh et al., 2008; Adikwu and Nnamani, 2005).

Prosopis africana leafs extracts have hepatoprotective properties (Ojo et al., 2006), this was associated with the high tannin level in the leaves. P. africana is a leguminous plant; it is a flowering plant named differentially as "kiriya" in Hausa, "open" in Ibo and Idoma and "gbaaye" in Tiv languages of Nigeria. The leaves, branches, bark, and roots are used for different purposes in local medicines (Kalinganire et al., 2007). The tree is about $12-18 \mathrm{~m}$ tall; the dry pods have 10$15 \mathrm{~cm}$ length and about $2 \mathrm{~cm}$ in thickness (Ogunshe et $a l .$, 2007).The seed is frequently used in Nigeria as seasoning and formulation of animal feed (Aremu et al., 2006). Thus, this study was designed to check the effect of fermented $P$. Africana seeds extract with methanol, after inducing paracetamol to cause liver damage in Wistar albino rats.

\section{Materials and Methods}

Collection of plant material. The seeds of $P$. africana were obtained from Ogige Market - Nsukka - Nigeria 
and fermented for twenty-four hours in chloroformmethanol.

Preparation of paracetamol (Acetaminophen). The purchased paracetamol was the product of Emzor pharmaceutics, five tablets of $500 \mathrm{~g}$ each were ground and $2500 \mathrm{mg} / \mathrm{kg} \mathrm{BW}$ was suspended in normal saline before oral administration, following Mitchell et al. (1973) method.

Extraction of seeds. The extraction was performed in line with Folch et al. (1957) method.

Experimental design. Thirty-two albino rats with weight-120-180 g were applied during this investigation. The subjects were housed and fed with water ad libitum for seven days prior to the experiment. After acclimatization, eight groups of the animals were separated with four rats per group. The administration of the extracts was made by oral intubation tube. The groups and doses administered are summarised in groups as outline stepwise.

Group one: received $5 \mathrm{~mL} / \mathrm{kg}$ of normal saline for 14 days (Normal rats and control).

Group two: received 2,500 $\mathrm{mg} / \mathrm{kg}$ of paracetamol suspension on day 7 and day 14 (Positive control).

Group three: received $100 \mathrm{mg} / \mathrm{kg} \mathrm{BW}$ of extract for 14 days.

Group four: received $400 \mathrm{mg} / \mathrm{kg} \mathrm{BW}$ of extract for 14 days.

Group five: received $100 \mathrm{mg} / \mathrm{kg} \mathrm{BW}$ of extract + $2500 \mathrm{mg} / \mathrm{kg}$ of paracetamol for seven days. Note that paracetamol was administered after 30 mins of administrating extract on the $7^{\text {th }}$ day, while the extract administration on this group proceeded for the next seven days.

Group six: received $400 \mathrm{mg} / \mathrm{kg} \mathrm{BW}$ of extract + paracetamol $2500 \mathrm{mg} / \mathrm{kg}$. (The same as group 5)

Group seven: received $2500 \mathrm{mg} / \mathrm{kg}$ paracetamol + $100 \mathrm{mg} / \mathrm{kg}$ BW of extract. Paracetamol was given on the $1^{\text {st }}$ day while treatment with the extract commenced after $24 \mathrm{~h}$ for 14 days.

Group eight: received $2500 \mathrm{mg} / \mathrm{kg}$ paracetamol + $400 \mathrm{mg} / \mathrm{kg}$ bw of extract. (The same as group 7) Groups five and six represent the ameliorating effects of the extract on the liver marker enzymes while groups 7 and 8 represent the curative effects of the extract.

Blood was collected into sample bottles via retrobulbar plexus in the eye and mixed with $10 \% \mathrm{w} / \mathrm{v}$ anticoagulant in distilled water to prevent clotting. The assay for serum biochemical and hematological parameters was collected and analyzed intermittently on the $7^{\text {th }}$ and $14^{\text {th }}$ day.

Acute toxicity analysis of $\boldsymbol{P}$. africana seeds extracted with methanol. The Lorke (1983) method was employed to determine the short (acute) toxicity of the P. africana seeds extracted with methanol in eighteen Wistar albino rats.

Induction of liver damage. Mitchell et al. (1973) method was used for the induction of liver damage in rats. Dacie and Lewis (1991) technique were employed to assay the hematological parameters of rats treated with $P$. africana seeds, extracted with methanol.

The assay of packed cell volume (PCV). PCV was assayed with microhaematocrit technique, where a mixed whole blood was permitted to enter capillary hematocrit duct together with anticoagulant until they are close to $-2 / 3$ filled with blood. Blood was filled inside a plastic - sealed tube and placed in the medial groves. All tubes were spun for five minutes at 1000 rpm and calculated using equation 1 .

$$
\operatorname{PCS}(\%)=\frac{\text { Height of cell column }}{\text { Height of total blood column }} \times 100
$$

where: $\mathrm{PVC}=$ pack cell volume

The assay of HB (hemoglobin) concentration. Whenever a whole blood is added into Drabkin's reagent, a solution - $\mathrm{KCN}$ and kite $(\mathrm{CN})_{6}, \mathrm{KCN}$ will convert $\mathrm{Hb}-\mathrm{Fe}^{2+}$ (ferrous) into $\mathrm{Hb}-\mathrm{Fe}^{3+}$ (ferric), resulting in the formation of methaemoglobin which later combines with $\mathrm{KCN}$ to produce a stable pigment-cyanmethaemoglobin complex. The intensity of this colour mixture is measured in a spectrophotometer at $540 \mathrm{~nm}$.Optical density (OD) of the solution will be proportional to the hemoglobin concentration. All forms of $\mathrm{Hb}-\mathrm{Hb}-\mathrm{C}$, and $\mathrm{Hb}-\mathrm{O}$, except $\mathrm{Hb}-\mathrm{S}$, are determined by cyanate-technique. A $5.0 \mathrm{~mL}$ of Drabkin's reagent was pipetted into two test tubes 1 and 2 and a thoroughly mixed sample of EDTA treated blood $(0.02 \mathrm{~mL})$ was pipetted into the tubes, rinsing the pipette five times with the reagent, until all the blood was removed from the pipette. The solutions allowed standing at $25^{\circ} \mathrm{C}$ for $10 \mathrm{~min}$ in order to allow the formation of cyano-methaemoglobin. The mixtures were read with a spectrophotometer at $540 \mathrm{~nm}$ by setting the percentage transmittance at 100\%. The Drabkin's 
reagent in tube 1 was used as a blank. The results were recorded using a pre-calibrated chart while $\mathrm{Hb}$ values in $\mathrm{g} / \mathrm{dL}$ were determined.

The assay of white blood cells (WBCs) counts. Whenever whole blood is added to a solution of weak acids, their dilutions will haemolyse the red blood cells and enable the counting of white blood cells.

Filling counting chamber. Approximately $0.02 \mathrm{~mL}$ of well-mixed EDTA-anticoagulated blood sample was added to $0.38 \mathrm{~mL}$ of diluted liquid and dispensed into a small container. One of the grids of the counting chamber was filled with re-mix of the diluted blood sample using a Pasteur pipette. The filled area was left 2 min to allow time for the white blood cells to settle, after which the underside of the chamber was dried and viewed with a microscope.

Counting of white blood cells. Using the $\mathrm{x} 10$ objective with the condenser iris closed considerably to give good contrast, the ruling of the chamber and white cells were focused until the cells appeared as small black spots. The cells which are in the four extended squares of the chamber were counted squarely and calculated.

The counting and assay of red blood cell (RBCs). Principle: Whenever whole blood is diluted with isotonic liquid, it averts lysis and promotes the counting of RBCs. Also, some employed isotonic solutions include Hayem's solution and $0.85 \%$ sodium chloride $(\mathrm{NaCl})$ solutions.

By adopting Thoma (manual) counting approach, anticoagulated $0.5 \mathrm{~mL}$ of blood was pipetted and diluted to a $101 \mathrm{~mL}$ with $\mathrm{RBC}$ diluting fluid (1: 200 dilution). Dilution was repeated in replicate. The chamber was filled by first expelling drops of the mixture and allowed for approximately $3 \mathrm{~min}$. The red cells were counted and calculated using equation 2

$$
\mathrm{RBC}=\mathrm{CC} \times \mathrm{CV} \times \mathrm{CD}
$$

where:

$\mathrm{RBC}$ is red blood cells (in $\mathrm{mm}^{3}$ )

$\mathrm{CC}$ is cells counted

$\mathrm{CV}$ is a correction for volume

$\mathrm{CD}$ is a correction for dilution

Number of RBCs counted in five squares $\times 10^{4}$.

Determination of aspartate aminotransferase (AST). For determination of AST, alanine aminotransferase
(ALT), alkaline phosphatase (ALP) methods of Klein et al. (1960) and Reitman and Frankel (1957) were used. Modified method by Shinde et al. (1999) was used to determine the effect of the extract on membrane stabilization, by evaluating the hypo tonicity-induced haemolysis of human red blood cells.

Statistical analysis. The T-test and one-way analysis of variance was applied to compare between groups and significance level was accepted at $p<0.05$.Data are presented in mean \pm standard deviation.

\section{Results and Discussion}

Paracetamol is a known antipyretic and analgesic drug which can cause liver necrosis if taken in an increased dosage. It eliminates sulphate and glucuronide conjugate (Mitchell et al., 1973). Taking paracetamol at high doses may cause the sulphation and glucuronidation pathway to attain saturation state. Thus, at a higher dosage of paracetamol, cytochrome-P 450 converts it into a highly reactive $\mathrm{N}$-acetyl- $p$-benzoquinoline. The inhibitor of CYPs curtails the toxicity of paracetamol (Tanaka and Misawa, 2000). A radical of semiquinone gotten from one electron can cause the deregulation of N-acetyl- $p$ benzoquinoline, by covalently binding to cellular membrane macromolecules, which causes elevation of lipid peroxidation and tissue damage. At a higher dosage of paracetamol and $\mathrm{N}$-acetyl-p-benzoquinoline may alkylate by oxidizing the intracellular GSH which reason the deregulation of liver GSH pool, proceeding to increase lipid peroxidation; thereby potentiating liver damage (Arnaiz et al., 1995). The choice of $P$. africana was based on its pharmacological properties as reported by Arbonnier (2002). In this study, the potential effect of $P$. africana seeds on - alkaline phosphatase, alanine aminotransferase, aminotransferase aspartate and other hematological parameters were investigated that are indicators of liver damage. The $\mathrm{LD}_{50}$ of the extract of P. africana did not show toxic effects at $5000 \mathrm{mg} / \mathrm{kg}$ b.w., suggesting the safety level of the seed extract if used at a high dosage (Table 1). The high degree of safety is consistent with the popular use of the fermented seed as food condiment to enhance the flavors of foods (Achi, 2005).

The packed cell volume, and hemoglobin level of the experimental animals in groups 5,6 and 7 was treated with $100 \mathrm{mg} / \mathrm{kg} \mathrm{BW}$ of paracetamol, and later treated with $400 \mathrm{mg} / \mathrm{kg} \mathrm{BW}$ of the extract (Fig. 1). PCV expressed the packed red blood cells (RBC) in percentage 
Table 1. Median lethal dose of $P$. africana seeds extract.

\begin{tabular}{lll}
\hline \hline Group & Dose $(\mathrm{mg} / \mathrm{kg}) \mathrm{BW}$ & Mortality \\
\hline Phase one & & \\
Group one & 10 & $0 / 3$ \\
Group two & 100 & $0 / 3$ \\
Group three & 1000 & $0 / 3$ \\
Phase two & & \\
Group one & 1600 & $0 / 3$ \\
Group two & 2900 & $0 / 3$ \\
Group three & 5000 & $0 / 3$ \\
\hline \hline
\end{tabular}

by volume of a whole blood sample after centrifugation (Wynne and Edwards, 2003).

The hemoglobin $(\mathrm{Hb})$ assay ascertained the volume of $\mathrm{Hb} \mathrm{g} / \mathrm{dL}$ of whole blood and quantified the oxygencarrying ability of the red blood cells. The increase in PCV and hemoglobin concentration may suggest that the rats were not anemic and the oxygen-carrying capacity of the animals was not compromised. A significant $(p<0.05)$ decrease in the PCV of group 2 (paracetamol group) compared with the group 1 (control group) suggests that the animals were anemic due to

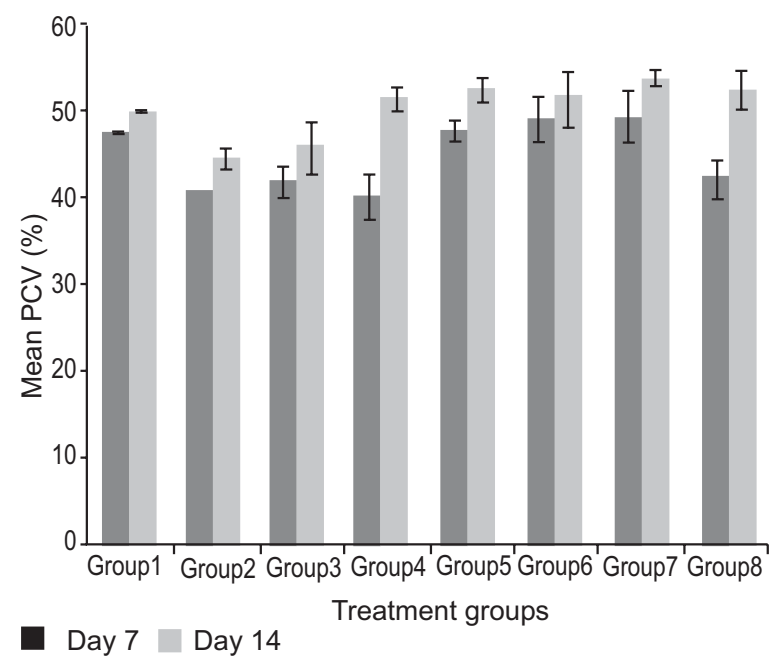

Group one $=$ Normal control; Group two $=$ Paracetamol $(2500 \mathrm{mg} / \mathrm{kg}$ BW); Group three $=100 \mathrm{mg} / \mathrm{kg} \mathrm{BW}$ of extract; Group four $=400 \mathrm{mg} / \mathrm{kg}$ BW of extract; Group five $=100 \mathrm{mg} / \mathrm{kg}$ BW of extract + paracetamol; Group six $=400 \mathrm{mg} / \mathrm{kg}$ BW of extract + paracetamol; Group seven $=$ paracetamol $+100 \mathrm{mg} / \mathrm{kg} \mathrm{BW}$ of extract; Group eight $=\mathrm{PCM}+$ $400 \mathrm{mg} / \mathrm{kg} \mathrm{BW}$ of extract;

Fig. 1. Effect of Prosopis africana seed extract on packed cell volume after paracetamolinduction of liver damage in rats damage caused to the liver via paracetamol-induction (Fig. 2).

A significant $(\mathrm{p}<0.05)$ increase was recorded for total white blood cell of groups 3, 4, 5 and 6 rats, respectively, compared to group 2 (paracetamol group). WBC represents the cubic millimeter of whole blood and usually beneficial in defending the body to avoid infections (Schalm et al., 1975). The increase in WBC count could be a result of the response to the induced liver damage that lead to the mobilization of the white cells. Though WBC counts increase rapidly, following an external attack by exogenous factors in response to boosting the body defense mechanism (Eyong et al., 2004). This explains the cause for the increased WBC count (Fig. 3). The significant $(\mathrm{p}<0.05)$ decrease in group 2 (paracetamol group) compared to the control group suggests suppression in WBC production due to paracetamol induction.

The elevation in $\mathrm{RBC}$ counts of the test groups was recorded, though the elevation was not significant $(p>$ 0.05 ) relative to group 2 (paracetamol group), except for group 3 administered $100 \mathrm{mg} / \mathrm{kg}$ BW of extracts

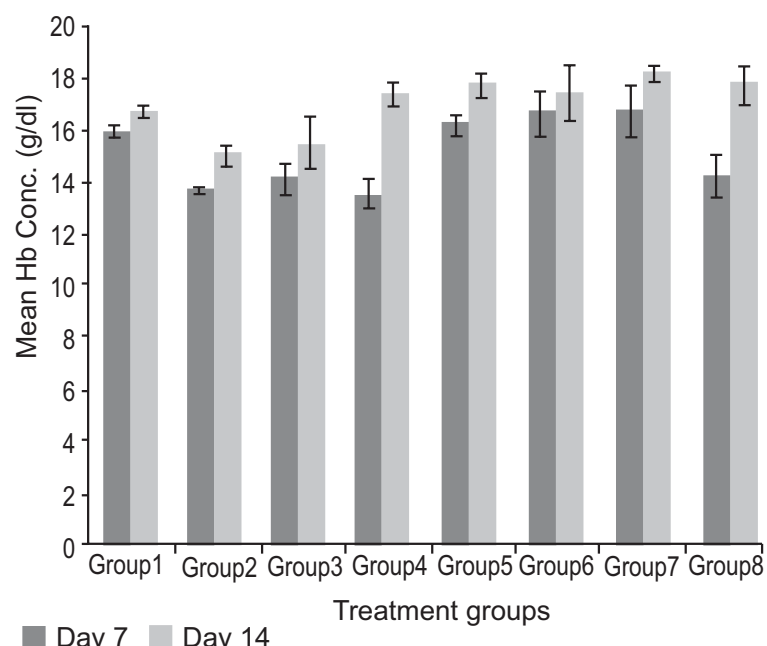

Group one $=$ Normal control; Group two $=$ Paracetamol $(2500 \mathrm{mg} / \mathrm{kg}$ BW); Group three $=100 \mathrm{mg} / \mathrm{kg} \mathrm{BW}$ - extract; Group four $=400 \mathrm{mg} / \mathrm{kg}$ BW - extract; Group five $=100 \mathrm{mg} / \mathrm{kg} \mathrm{BW}$ - extract + Paracetamol; Group six $=400 \mathrm{mg} / \mathrm{kg} \mathrm{BW}-$ extract + paracetamol; Group seven = Paracetamol $+100 \mathrm{mg} / \mathrm{kg} \mathrm{BW}$ - extract; Group eight $=$ Paracetamol $+400 \mathrm{mg} / \mathrm{kg} \mathrm{BW}$ - extract;

Fig. 2. Effect of Prosopis africana seeds extract on haemoglobin concentration in paracetamol-induced liver damage of rats 


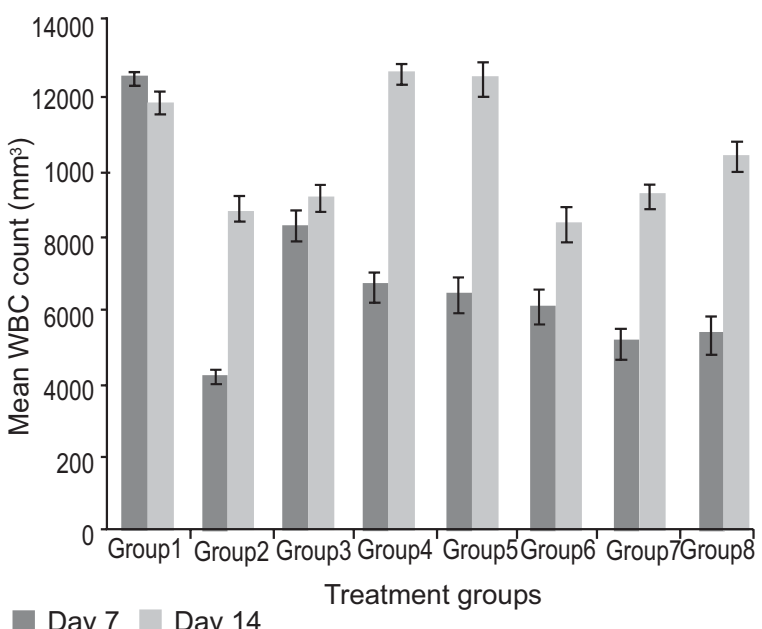

Day 7 Day 14

Group one $=$ Normal control; Group two $=$ Paracetamol $(2500 \mathrm{mg} / \mathrm{kg}$ BW); Group three $=100 \mathrm{mg} / \mathrm{kg} \mathrm{BW}$ - Extract; Group four $=400 \mathrm{mg} / \mathrm{kg}$ BW - Extract; Group five $=100 \mathrm{mg} / \mathrm{kg} \mathrm{BW}$ of Extract + Paracetamol; Group six $=400 \mathrm{mg} / \mathrm{kg}$ BW of Extract + paracetamol; Group seven $=$ Paracetamol $+100 \mathrm{mg} / \mathrm{kg} \mathrm{BW}-$ Extract; Group eight $=$ Paracetamol $+400 \mathrm{mg} / \mathrm{kg} \mathrm{BW}$ - extract;

Fig. 3. Effect of methanol seed extract of Prosopis africana on total white blood cell count in paracetamol-induced liver damage in rats

only. The main role of RBC is to transport oxygen to all organs, including lungs as well as transport carbon (IV) oxide from the cells to the lungs (Nelson and Cox, 2000). It was conceived that the extract may contain some mineral such as iron that helps to boost the iron level to transport oxygen to the cells. A decrease observed in group 2 (paracetamol group) as compared to normal control (group 1) was attributed to the RBCs destruction in the spleen (hypersplenism), that acquired alterations in the red cell membrane of group 2 rats induced with paracetamol (Fig. 4).

The assay of enzyme activities such as ALT and AST for assessment of paracetamol-induced liver damage or any other hepatotoxin are frequently used (Dobbs et al., 2003). Enzymes are released into circulation due to necrosis or membrane damage, thus, it is measured in serum or whole blood. In the mitochondriahepatocytes, AST and ALT are predominantly localized in the liver. Therefore, it is an appropriate marker to check for liver impairment or insufficiency. Serum ALP is also associated with liver cell damage. Increase in the activity of these enzymes would suggest liver impairment. Administration of paracetamol caused a considerable increase of AST, ALT and ALP activities,

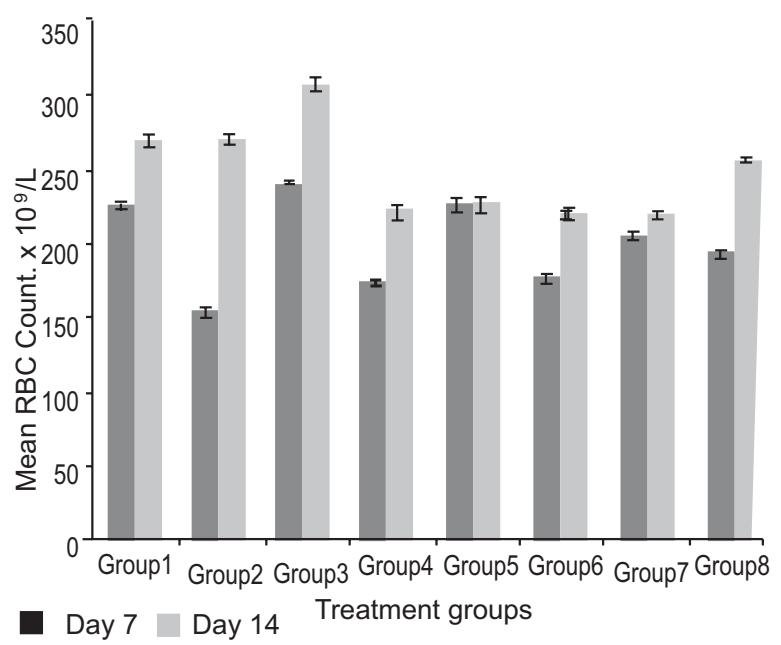

Group one $=$ Normal control; Group two $=$ Paracetamol $(2500 \mathrm{mg} / \mathrm{kg}$ $\mathrm{BW}$ ); Group three $=100 \mathrm{mg} / \mathrm{kg}$ BW - Extract; Group four $=$ Extract - 400mg $/ \mathrm{kg} \mathrm{BW}$; Group five $=100 \mathrm{mg} / \mathrm{kg} \mathrm{BW}-$ Extract + Paracetamol; Group six $=400 \mathrm{mg} / \mathrm{kg} \mathrm{BW}$ of Extract + Paracetamol; Group seven $=$ Paracetamol $+100 \mathrm{mg} / \mathrm{kg} \mathrm{BW}-$ Extract Group eight $=$ Paracetamol $+400 \mathrm{mg} / \mathrm{kg} \mathrm{BW}$ - extract

Fig. 4. Effect of methanol seed extract of Prosopis africana on red blood cell count in paracetamol-induced liver damage in rats

exemplified in Fig. 5-7, respectively. The damage caused to the conformation of the liver was due to the permeability of paracetamol into the cytoplasmic domain which provoked the release of these enzymes into the bloodstream after cellular damages, which suggest the onset of hepatotoxicity (Sallie et al., 1991).

There was a significant $(\mathrm{p}<0.05)$ elevation in the activities of ALT and AST of group 2 rats compared with the rats in normal control (group 1). The result of this study also shows a reasonable reduction in the AST level of groups 6,7 and 8 rats treated with $400 \mathrm{mg} / \mathrm{kg}$ BW of extract after $100 \mathrm{mg} / \mathrm{kg}$ BW paracetamol induction. The $400 \mathrm{mg} / \mathrm{kg} \mathrm{BW}$ of the extract was administered after paracetamol induction, it was compared with group 2 (paracetamol group) to establish the variation in the effect of paracetamol. The result deduced that at a higher dose $-400 \mathrm{mg} / \mathrm{kg} \mathrm{BW}$ of the extract, the injurious effects of paracetamol were overcome. Furthermore, the 100 and $400 \mathrm{mg} / \mathrm{kg} \mathrm{BW}$ of the extract administered after paracetamol induction was able to ameliorate the damage to an extent. Significant $(p<0.05)$ reduction was recorded in the ALT activity of all the test groups compared with group 2 (paracetamol group). This result actually indicates 
the protective and ameliorative effect of the extract since ALT is more localized in the liver. Thus it is a better marker of effect for estimating liver injury. Its protective activity indicates that hepatic tissue damage was repaired and plasma membrane stabilized. This could be attributed to flavonoids and alkaloids in the extract. The lower and normal (ALT and AST) activities suggest vitamin B6 deficiency. The results of AST and ALT agreed with an earlier report by Ramadoss et al. (2011) and Ojo et al. (2006). The liver injury was caused by the toxicity of paracetamol, which caused an increase in the levels of serum alkaline phosphatase (ALP) (Rajesh and Latha, 2004). ALP elevation in group 2 rats compared with the normal group could be associated with cholestasis due to biliary obstruction or hepatic infiltration of rats in group 2. Day 7 shows a nonsignificant $(p>0.05)$ increase of ALP activity in all the test groups when compared with the control groups (group 1 and 2), while day 14 shows a non-significant $(\mathrm{p}>0.05)$ decrease in groups $4,5,6,7$ and 8 rats, compared groups 1 and 2 . This result suggests that the extract was able to regenerate the damaged hepatic cells with time. Furthermore, ALP activity of group 3 rat's administered $100 \mathrm{mg} / \mathrm{kg} \mathrm{BW}$ of extract only was found to be elevated as compared with the control groups throughout the experiment. This result implies that the extract was not able to control the activity of ALP. It was reported that effective control of alkaline phosphatase activity is associated with the early improvement and repair of the mechanism of secreting the hepatic cells (Mason, 2004).

The extract was effective in ameliorating paracetamol effect on live damage in this study. These parameters were repaired or reinvigorated - plasma membrane stabilization, and repair of liver tissue damage. The result resorts that transaminase activities reversed to the normal healing process of the liver- parenchyma cells and the regeneration of liver tissues (Shukla et al., 1992; Thabrew et al., 1987). P. africana seed extract showed stabilization of membrane versus hypotonicityinduced hemolysis with the human red cells. The inhibition of induced-hemolysis is outlined in Table 2. The shrinkage of cells due to loss of osmotic intracellular electrolyte may cause hemolysis to arise. The processes that play a role in stimulating the efflux of intracellular components was inhibited by extract after administration. The induction of hemolysis via hypotonicity of red blood cells usually occurs because of uptake of water cells, which triggered the release of hemoglobin to absorb maximally at $418 \mathrm{~nm}$. The hemolysis inhibition was dose-dependent, i.e. the response of the cell was increasing as the concentration of the extract increased. A dose-dependent decrease in the optical density shows a corresponding amount of hemoglobin released into the medium. Any toxicity usually results in distortion of liver membrane integrity due to hepatocellular damage and a rise in plasma levels $r$, a consequence of high toxin levels in hepatocytes. The stabilizing effect of this extract on lysosomal membranes suggests a possible action of anti-inflammation. This result corroborated the findings of Anosike and Obidua (2010) and Iwueke et al. (2006) who reported the stabilization of hepatocyte membrane with coconut extract and Vitex doniana leaves.

\section{Conclusion}

Following the result, one can infer that Prosopis africana seeds extracted with methanol have significant action on liver damage caused by paracetamol-induced hepatotoxicity. It is therefore, suggested that incorporation of $P$. africana seeds in the human diet may help prevent liver ambulation, ameliorate enzymes leakage and protect against liver damage.

Table 2. Effect of Prosopis africana seed extract on hypotonicity-induced hemolysis of human red blood cells

\begin{tabular}{lllllll}
\hline \hline Treatment & $\begin{array}{l}\text { Extract } \\
\text { concentration } \\
(\mathrm{mg} / \mathrm{mL})\end{array}$ & $\begin{array}{l}\text { Normal } \\
\text { saline }(\mathrm{mL})\end{array}$ & $\begin{array}{l}\text { Distilled } \\
\text { water }(\mathrm{mL})\end{array}$ & $\begin{array}{l}\text { RBC } \\
(\mathrm{blood}) \\
(\mathrm{mL})\end{array}$ & $\begin{array}{l}\text { Absorbance } \\
\%\end{array}$ & $\begin{array}{l}\% \\
\text { inhibition } \\
\text { of haemolysis }\end{array}$ \\
\hline $\begin{array}{l}\text { Isotonic } \\
\text { solution }\end{array}$ & - & 1.8 & - & 0.2 & 0.051 & - \\
$\begin{array}{l}\text { Hypotonic } \\
\text { solution }\end{array}$ & - & 0.6 & 1.2 & 0.2 & 0.701 & - \\
$\quad \begin{array}{l}\text { Test-sample } \\
\text { Test-sample }\end{array}$ & 0.1 & 0.2 & 1.2 & 0.2 & 0.258 & 63.2 \\
$\quad \begin{array}{l}\text { Test-sample } \\
\text { Test-sample }\end{array}$ & 0.4 & 0.4 & 1.2 & 0.2 & 0.146 & 79.2 \\
\hline \hline
\end{tabular}


Conflict of Interest. The authors declare no conflict of interest.

\section{References}

Achi, O.K. 2005. The potential for upgrading traditional fermented foods through biotechnology. African Journal of Biotechnology, 4: 375-380.

Adikwu, M.U., Nnamani, P.O. 2005. Rheological property of mucin. Bioresearch Journal, 3: 1-6.

Anosike, C.A., Obidoa, O. 2010. Anti-inflammatory and anti-ulcerogenic effect of ethanol extract of coconut (Cocos nucifera) on experimental rats. African Journal of Food Agriculture, Nutrition, and Development, 10: 4286-4300.

Arbonnier, M. 2002. Trees, Shrubs, and Lianas of West African Dry Zones. pp. 189-426, Cirad Margraf Publishers, Paris, France.

Dacie, J.V., Lewis, S.M. 1991. Practical Haematology. $7^{\text {th }}$ edition. pp. 535-544, Churchill Livingstone, Edinburgh, UK.

Dobbs, N.A., Twelves, C.J., Gregory, W., Cruickshanka, C., Richards, M.A., Rubens, R.D. 2003. Epirubicin in patients with liver dysfunction. Development and evaluation of a novel dose modification scheme. European Journal of Cancer, 39: 580-586.

Eyong, E.U., Umoh, I.B., Ebong, P.E., Eteng, M.U., Antai, A.B., Akpa, A.O. 2004. Haemotoxic effects following ingestion of Nigerian crude oil polluted shellfish by rats. Nigerian Journal of Physiological Sciences, 19: 1-6.

FAO, 1996. Some medicinal forest plants of Africa and Latin America. Journal of Science, 67: 75-78, 161162.

Folch, J., Lees, M., Stanley, G.H.S. 1957. A simple method for the isolation and purification of total lipids from animal tissues. The Journal of Biological Chemistry, 226: 497-509.

Gilbert, S.B., Neil, R.A. 1986. The Theory Practice of Industrial Pharmacy, $4^{\text {th }}$ edition. pp. 294-298, Lea and Febiger, Philadelphia, USA.

Iwueke, A.V., Nwodo, O.F.C., Okoli, C.O. 2006. Evaluation of the anti-inflammatory and analgesic activities of Vitex doniana leaves. African Journal of Biotechnology, 5: 1929-1935.

Kalinganire, A., Weber, J.C., Uwamariya, A., Kone, B. 2007. Improving Rural Livelihoods through Domestication of Indigenous Fruit Trees in Parklands of the Sahel. In: Indigenous Fruit Trees in the Tropics: Domestication, Utilization, and
Commercialization. FK Arimifesi et al. (eds.) pp.186-203, CAB International Publising, Oxfordshire, UK.

Klein, B., Read, P.A., Babson, L.A. 1960. A rapid method for the quantitative determination of serum alkaline phosphatase. Clinical Chemistry, 6: 269275.

Kolapo, A.L., Okunade, M.B., Adejumobi, J.A., Ogundiya, M.O. 2009. Phytochemical composition and antimicrobial activity of Prosopis africana against some selected oral pathogens. World Journal of Agricultural Sciences, 5: 90-93.

Lawal, I.O., Uzokwe, N.E., Igboanugo, A.B.I., Adio, A.F., Awosan, E.A., Nwogwugwu, J.O., Faloye, B., Olatunji, B.P., Adesoga, A.A. 2010. Ethnomedicinal information on collation and identification of some medicinal plants in research institutes of south-west Nigeria, African Journal of Pharmacy and Pharmacology, 4: 001-007.

Lorke, D. 1983. Determination of acute toxicity. Archives Toxicity, 53: 275-279.

Mason, P. 2004. A blood test used to investigate liver, thyroid or kidney function and disease. Journal of Pharmacy, 272: 446-448.

Mitchell, J.R., Jollow, D.J., Potter, W.Z., Gillette, J.R., Brodie, B.B. 1973. Acetaminophen-induced hepatic necrosis. IV. Protective role of glutathione. Journal of Pharmacology Experimental Therapeutics, 187: 211-217.

Momoh, M.A., Adikwu, M.U., Eraga, S.O. 2008. The effect of cast films of bovine mucin and Prosopis gum containing a cicatrin ${ }^{\circledR}$ powder on wound healing. Dhaka University Journal of Pharmaceutical Science, 7: 7-10.

Nelson, D.L., Cox, M.C. 2000. Lehninger's Principles of Biochemistry. $3^{\text {rd }}$ edition, pp. 120, 631, 842-843, Worth Publishers, New York, USA.

Ngo-Bum, E., Taiwe, G.S., Nkaissa, L.A., Moto, F.C.O., Seke, E.P.F., Hiana, I.R., Bailabar, T., Rouyatou, S.P., Rakotonirina, A., Rakotonirina, S.V. 2009. Validation of anticonvulsant and sedative activity of six medicinal plants. Epilepsy and Behaviour, 14: 454-458.

Ogunshe, A.A.O., Omotosho, M.O., Ayanshina, A.D.V. 2007. Microbial studies and biochemical characteristics of controlled fermented Afiyo-a Nigerian fermented food condiment from Prosopis africana (Guill and Perr.) Taub, Pakistan Journal of Nutrition, 6: 620- 627.

Ojo, O.O., Nadro, M.S., Tela, I.O. 2006. Protection of 
rats by some common Nigerian trees against acetaminophen-induced hepatotoxicity. African Journal of Biotechnology, 5: 755-760.

Osho, I.B., Lajide, L. 2012. Pre-screening evaluation of some plant extracts used in ethnoveterinary practices as antitrypanosomal agents. Journal of Medicinal Plants Research, 6: 2056-2060.

Rajesh, M.G., Latha, M.S. 2004. Preliminary evaluation of the antihepatotoxic activity of Kamilari, a polyherbal formulation. Journal of Ethnopharmacology, 91: 99-104.

Ramadoss, S., Kannan, K., Balamurugan, K., Jeganathan, N.S., Manavalan, R. 2011. Hepatoprotective effects of cyathula prostrate Linn. in paracetamol-induced liver injury in rats, Journal of Pharmaceutical Research and Opinion, 1: 178-180.

Reitman, S., Frankel, S. 1957. A colorimetric method for the determination of serum glutamic oxaloacetic and glutamic pyruvic transaminases. American Journal of Clinical Pathology, 28: 56-63.

Schalm, O.W., Jain, N.C., Carrol, E.J. 1975. Veterinary Haematology, $3^{\text {rd }}$ edition, pp. 421-538. Lea and
Febiger, Philadelphia, USA.

Shinde, U.A., Phadke, A.S., Nair, A.M., Mungantiwar, A.A., Dikshit, V.J., Saraf, V.O. 1999. Membrane stabilizing activity-a possible mechanism of action for the anti-inflammatory activity of Cedrus deodara wood oil. Fitoterapia, 70: 251-257.

Shukla, B., Visen, S., Patnaik, G.K., Tripathi, S.C., Srimal, R.C., Day, S., Dobhal, P.C. 1992. Hepatoprotective activity in the rat of ursolic acid isolated from Eucalyptus hybrid. Phytotherapy Research, 6: 74-79.

Tanaka, E.M., Misawa, S. 2000. Cytochrome P-450 2E9: Its clinical and toxicological role. Clinical Therapeutics, 25: 165-175.

Thabrew, M.I., Joice, P.D., Rajatissa, T.M. 1987. Comparative study of the efficacy of Pavetta indica and Osbeckia octandra in the treatment of liver function. Planta Medica, 53: 239-241.

Wynne, H.A., Edwards, C. 2003. Laboratory Data. In: Clinical Pharmacy and Therapeutics. Roger, W. and Clive, E. (eds.). pp 58-61, $3^{\text {rd }}$ edition, Elsevier, Philadelphia, USA. 